\title{
Art appreciation in cultural arts subject
}

\author{
Apresiasi seni dalam mata pelajaran seni budaya
}

\author{
Wulandari \\ Social Education Program, Postgraduate Faculty, Universitas Negeri Padang
}

\begin{abstract}
This research begins with the finding that the students of class VII who do not appreciate the various arts presented by class IX on art performances held in school. This can be evidenced by the loneliness of his students watching art performances at school because the majority of VII grade students roam the school. As if not concerned with the various artistry that is displayed. This research uses qualitative method. Application of research informants conducted. Determination of research informants conducted by Purposive sampling. Data were collected using observation, interview and documentation techniques. The technique of guaranteeing the validity of the data guarantees the data of this study using triangulation, Data Analysis model Miles dab Hubberman method using three steps consisting of data reduction, data presentation and verification or conclusion. The result of the analysis shows that: the factors that cause the less appreciation of the students of VII and the students of class VII are: (1) the lack of students' understanding of the displayed art, (2) the interesting or unattractive influence of art displayed, (3) puberty, of them come to school just to play around in groups. In the case of the highly needed teacher's ability in the field of art and culture studies to more in depth provide learning to students of class VII and class VIII so they are more appreciative, and can assess every art that is displayed.
\end{abstract}

Keywords: Art appreciation, art and culture

This is an open access article distributed under the Creative Commons Attribution License, which permits unrestricted use, distribution, and reproduction in any medium, provided the original work is properly cited. $\odot 2018$ by author

\section{PENDAHULUAN}

Apresiasi seni merupakan suatu proses sadar yang dilakukan seseorang dalam menghadapi dan memahami karya seni. Mengapresiasi adalah sebuah proses untuk menafsirkan sebuah makna yang terkandung dalam karya seni. Seorang pengamat seni yang sedang memahami karya seni sebaiknya terlebih dahulu mengenal struktur bentuk karya seni, pengorganisasian elemen seni atau dasar-dasar penyusunan dari karya yang sedang dihayati. Lebih jauh lagi seorang pengamat seni berkewajiban mengenal struktur dasar seni. Memahami estetika dalam seni merupakan salahsatu wujud pelaksanaan apresiasi, dan merupakan suatu proses penyadaran yang dilakukan penikmat dalam menghadapi dan menghargai sebuah karya seni. Apresiasi adalah proses mengenalan nilai-nilai seni, untuk menghargai dan menafsirkan makna (arti) yang terkandung didalamnya. Apresiasi menuntut keterampilan dan kepekaan estetik guna mendapatkan pengalaman estetik ketika mengamati karya seni. Pengalaman estetik bukanlah sesuatu yang mudah muncul dengan sendirinya atau mudah diperoleh, karena memerlukan latihan dan perhatian yang sungguhsungguh. Pengalaman estetik dari seseorang adalah persoalan psikologis yang banyak dibahas dalam persoalan estetika.

Hal ini menimbulkan pertanyaan, bagaimana seseorang dapat menanggapi atau memahami bahwa suatu benda itu indah sebagai karya seni seseorang tidak lagi hanya membahas sifat dan kualitas diri wujud benda estetik, terutama usaha menguraikan dan menjelaskan secara cermat dan lengkap dari semua gejala psikologis yang berhubungan dengann dengan karya seni. Seseorang orang yang merasakan kepuasan setelah menikmati suatu karya, maka orang tersebut dapat dikatakan memperoleh kepuasan estetika yang merupakan kombinasi 
antara sikap subjektif dan kemampuan memunculkan persepsi secara kompleks. Pada dasarnya pengalaman estetik merupakan hasil dari imteraksi antara karya seni dengan penikmatnya. Interaksi tersebut tidak akan terjadi tanpa adanya suatu kondisi yang mendukung dalam penangkapan nilai seni yang terkandung dalam karya seni tersebut. Yaitu kondisi intelektual dan kondisi emosional. Steppen C. Pepper dalam The Liang Gie menulis pendekatan psikologis dengan mencontohkan kesenadaan membuat karya menjadi monoton, sedangkan kekacaubalauan yang berlebihan membuat karya menjadi tidak indah. Untuk mengatasi kedua faktor perusak pengalaman estetik itu, penyusunan karya seni harus diusahakan adanya keanekaan dan keseimbangan.

Apresiasi bukanlah sebuah proses pasif, ia merupakan proses aktif dan kreatif, agar secara efektif menegerti nilai suatu karya seni, dan mendapatkan pengalaman estetik. Adapun pengalaman estetik dinyatakan oleh John Dewey adalah pengalaman yang dihasilkan dari proses penghayatan karya. Seorang pengamat yang sedang memahami karya seni diharapkan terlebih dahulu mengenal struktur organisai atau dasar seni. Seorang pengamat yang kreatif akan dapat menangkap signal tersebut lewat daya kreasi imajinatifnya. Seorang pengamat dengan segala kemampuan berusaha menafsirkan lambing yang dihadirkan oleh sang seniman. Daya imaji merupakan hasil tanggapan sesaat indera yang kemudian mnghasilkan interaksi antara persepsi luar dan persepsi dalam. Hasil interaksi tersebut disebut interprestasi yang kemudian terkumpul sebagai nilai hayati, begitu juga kalau menghayati karya puisi, musik, tari, dan drama, maka sebenarnya kita berusaha memahami pesan seniman yang diinformasikan lewat karya seninya. Untuk memahami kesenian dibutuhkan pengalaman estetika bagi seorang penikmat, pengalaman yang ditemukan dari hasil penghayatan suatu karya seni, di samping tergantung pada karya seni itu sendiri, juuga terkandung pada kondisi intelektual serta kondisi emosional si penikmat. Seorang apresiator yang baik tentu paham akan sistem pengorganisasian karya seni antara lain mencakup, harmoni irama, pusat perhatian, proporsi, kontras, gradasi, serta hokum keseimbangan formil atau nonformil yang dihadirkan oleh sang senimannya, di samping itu juga seorang penimat harus memahami teknik dalam menghadirkan unsur tersebut dan tata cara mencapai nilai karakter khusus dari unsur yang dihadirkan. Maka dapat disimpulkan sementara, bahwa seorang apresiator yang baik harus mengalami atau mengenal teori dasar seni serta tata cara mewujudkan karya seni. Secara objektif seseorang harus dapat menangkap lambing atau symbol yang diinformasikan sang seniman terhadap penikmat, da seorang penimat harus dapat menafsirkan dengan segala pengalaman estetik dan intelektualnya guna menafsirkan lambing yang dihadirkan seniman.

\section{METODE}

Pengumpulan data dilakukan dengan observasi, wawancara dan studi pustaka. Dalam observasi dilihat langsung bagaimana apresiasi siswa terhadap mata pelajaran seni budaya guna memahami bagaimana cara mengaprsiasi yang baik dan benar. Setelah itu, dilakukan wawancara dengan nara sumber siswa kelas VII dan VIII MTsN Koto Tangah Padang dan guru seni budaya disekolah tersebut. Selanjutnya studi data tertulis digunakan sebagai acuan dalam menjelaskan dan/atau menganalisis permasalahan yang dibahas. Analisis dilakukan dengan pendekatan etnografi yang menunjukkan bagaimana tingkat apresiasi seni siswa terhadap pembelajaran seni budaya.Seni budaya sebagai sarana hiburan dan media pendidikan tradisional bagi siswa kelas VII dan VIII MTsN Koto Tangah Padang. Pemaparan hasil analisis dilakukan secara deskriptif.

\section{HASIL DAN PEMBAHASAN}

Apresiasi seni merupakan suatu proses sadar yang dilakukan seseorang dalam menghadapi dan memahami karya seni. Mengapresiasi adalah sebuah proses untuk menafsirkan sebuah makna yang terkandung dalam karya seni. Seorang pengamat seni yang sedang memahami karya seni sebaiknya terlebih dahulu mengenal struktur bentuk karya seni, pengorganisasian elemen seni atau dasar-dasar penyusunan dari karya yang sedang dihayati. Lebih jauh lagi seorang pengamat seni berkewajiban mengenal struktur dasar seni. Memahami estetika dalam seni merupakan salahsatu wujud pelaksanaan apresiasi, dan merupakan suatu proses penyadaran yang dilakukan penikmat dalam menghadapi dan menghargai sebuah karya seni. Apresiasi adalah proses mengenalan nilai-nilai seni, untuk menghargai dan menafsirkan makna (arti) yang terkandung didalamnya. Apresiasi menuntut keterampilan dan kepekaan estetik guna mendapatkan pengalaman estetik ketika mengamati karya seni. Pengalaman estetik bukanlah sesuatu yang mudah muncul dengan sendirinya atau mudah diperoleh, karena memerlukan latihan dan perhatian yang sungguhsungguh. Pengalaman estetik dari seseorang adalah persoalan psikologis yang banyak dibahas dalam persoalan estetika.

Dalam apresiasi, seorang penghayat sebenarnya sedang mencari pengalaman estetis. Sehingga motivasi utama yang muncul dari diri penghayat seni adalah motivasi untuk mencari pengalaman estetis. Pengalaman estetis menurut Albert R. Candler adalah kepuasan kontemplatif atau kepuasan intuitif. Sedangkan Yakob Sumardjo menjelaskan pengalaman seni adalah keterlibatan aktif dengan kesadaran yang melibatkan kecendekiaan, emosi, indera dan intuisi manusia dengan lingkungan (benda seni) (2000, 161). Dalam proses 
pengalaman estetis unsur perasaan dan intuisi lebih menonjol dibandingkan nalar; itulah sebabnya maka dalam proses tersebut penghayat seni seolah kehilangan jati dirinya karena seluruh kehidupan perasaannya larut ke dalam obyek seni, dan inilah yang disebut dengan empati.Berdasarkan hasil pengamatan peneiti dilapangan ditemukan bahwa apresiasi seni siswa terhadap pentas seni yang diadakan di sekolah masih lemah, karena ketika acara ditampilkan siswa kelas VI dan VII cenderung mengabaikan kesenian yang ditampilkan mayoritas dari mereka berkeliaran diluar sekolah dan sibuk terhadap aktivitas sendiri. Maka dari itu saran untuk guru yang mengajar agar memperdalam pengetahuan tentang seni budaya dan lebih kreatif lagi dalam menggunakan media pembelajaran agar siswa lebih tertarik akan pembelajaran seni budaya.

\section{KESIMPULAN}

Berdasarkan hasil penelitian di MTsN 3 Padang pada kelas VI semester ganjil tahun pelajaran 2017/2018 berdasarkan hasil penelitian dilapangan, maka dapat disimpulkan bahwa apresiasi seni siswa terhadap pentas seni yang diadakan di sekolah masih lemah, karena ketika acara ditampilkan siswa kelas VI dan VII cenderung mengabaikan kesenian yang ditampilkan mayoritas dari mereka berkeliaran diluar sekolah dan sibuk terhadap aktivitas sendiri. Maka dari itu saran untuk guru yang mengajar agar memperdalam pengetahuan tentang seni budaya dan lebih kreatif lagi dalam menggunakan media pembelajaran agar siswa lebih tertarik akan pembelajaran seni budaya.

\section{REFERENCES}

Ardipal. (2010). Kurikulum Pendidikan Seni Budaya yang Ideal Bagi Peserta Didik Dimasa Depan. Jurnal Penelitian.

Bahari, Nooryan. (2008). Kritik Seni “Wacana Apresiasi dan Kreasi”.Yogyakarta : Pustaka Pelajar.

Gie, The Liang. (1996). Filsafat Seni “Sebuah Pengantar”. Yogyakarta : Pusat Belajar Ilmu Berguna.

Gie, The Liang. (1996). Filsafat Keindahan. Yogyakarta : Kanisius.

Moleong, Lexy J. (2008). Metode Penelitian kualitatif. Bandung: PT. Remaja Rosda Karya.

Naisah. (2013).Pembelajaran Seni Budaya dan Keterampilan dengan Menggunakan Pendekatan Inkuiri di Sekolah dasar. Artikel Penelitian.

Prayitno. (2008). Pendidikan Dasar dan Teori Praktis.Jilid 1. Padang: Universitas Negeri Padang. Sumatera Barat.

Peraturan Menteri Pendidikan Nasional (Permendiknas) Republik Indonesia No 22 Tahun 2006 tentang standar penilaian pendidikan. (2006). Jakarta: Badan Standar Nasional Pendidikan.

Rondhi, Moh. (2017).Apresiasi Dalam Konteks Pendidikan Seni. Jurnal Penelitian.

Sudana, Nyoman. (1989). Ilmu Pengajaran: Taksonomi Variabel. Jakarta: Departemen Pendidikan Dan Kebudayaan.

Sudjana, Nana. (1991). Media pengajaran (penggunaan dan pembuatannya). Bandung: Sinar Baru.

Tarsa, Arnita. (2016). Apresiasi Seni "Imajinasi dan Kontemplasi Dalam Karya Seni. Forum Penelitian.

Cahyono, WahyuBudi. (2017). Pengelolaan Pembelajaran Seni BudayaDi Smp Negeri 1 Pulokulon Kabupaten Grobogan. Jurnal Penelitian.

Winkel, W. S. (1996). Psikologi Pengajaran. Jakarta: Gramedia.

Pekerti, Widia. (2008). Metode Pengembangan Seni. Jakarta : Universitas Terbuka.

Ispahani, V. S. (2011). Apresiasi Sebagai Salah Satu Pendekatan dalam Pembelajaran Seni Tari di Smp. Harmonia: Journal of Arts Research And Education, 11(1). 